Research article

\title{
CYTOLOGICAL AND MOLECULAR IDENTIFICATION OF HAEMOGREGARINA STEPANOWI IN BLOOD SAMPLES OF THE EUROPEAN POND TURTLE (EMYS ORBICULARIS) FROM QUARANTINE AT BELGRADE ZOO
}

\author{
ÖZVEGY Jòzsef ${ }^{1}$, MARINKOVIĆ Darko², VUČIĆEVIĆ Miloš, GAJIĆ Bojan ${ }^{4}$, \\ STEVANOVIĆ Jevrosima ${ }^{5}$, KRNJAIĆ Dejan ${ }^{6}$, ALEKSIĆ-KOVAČEVIĆ Sanja ${ }^{2 *}$ \\ ${ }^{1}$ Belgrade Zoo Garden, Belgrade, Serbia; ${ }^{2}$ Department of Pathology, Faculty of Veterinary Medicine, \\ University of Belgrade, Belgrade, Serbia; ${ }^{3}$ Department of Equine, Small Animal, Poultry and Wild \\ Animal Diseases, Faculty of Veterinary Medicine, University of Belgrade, Belgrade, Serbia; ${ }^{4}$ Department \\ of Parasitology, Faculty of Veterinary Medicine, University of Belgrade, Belgrade, Serbia; ${ }^{5}$ Department \\ of Biology, Faculty of Veterinary Medicine, University of Belgrade, Belgrade, Serbia; ${ }^{6}$ Department of \\ Microbiology, Faculty of Veterinary Medicine, University of Belgrade, Belgrade, Serbia
}

(Received 31 October; Accepted 27 November 2015)

Blood smears stained with Diff Quick are the initial tool for cytological diagnosis of Haemogregarina spp. However, the development of sensitive and specific molecular methods enabled the detection and identification of parasites in the sample and to clarify the evolutionary relationships of adeleorinid parasites within the Apicomplexa.

The current study was attempted in order to perform cytological investigation and molecular identification of the hemoparasites in thirty European pond turtles (Emys orbicularis) from the quarantine section at Belgrade Zoo, which have been found in poor health condition with massive skin hemorrhages, based on intraerythrocytic parasitic forms on hematological smears and $18 \mathrm{~S}$ rDNA sequence, respectively.

Different life cycle stages of the Haemogregarina sp. were noticed within the erythrocytes in the peripheral blood. Biochemical analysis indicated lower values of AST and iron in most of the infected turtles while hematological analysis showed a changed hematocrit value, a decrease in the number of red blood cells and low hemoglobin levels. Amplifications of the $18 \mathrm{~S} \mathrm{rDNA}$ sequence of Haemogregarina were detected in 30/30 $(100 \%)$ turtles with clinical symptoms. The identity of PCR products was confirmed by direct DNA sequencing. Future research concerning $H$. stepanowi in Serbia should be applied to its definitive host-the leech.

Key words: $18 \mathrm{~S}$ rDNA, Emys orbicularis, Haemogregarina stepanowi, Serbia, cytological investigation

\footnotetext{
*Corresponding author: e-mail: skovacevic@vet.bg.ac.rs
} 


\section{INTRODUCTION}

Genus Haemogregarina infects turtles living within or nearby freshwater habitats. Infected turtles are in poor health condition, with general weakness, low motility and anorexia. Necrotic ulcerations of the shell and skin as well as massive skin hemorrhages are common macroscopic findings [1]. Among reptiles, genus Haemogregarina Danilewsky, in 1885 included in Phylum Apicomplexa, Class Sporozoasida, Order Adeleina, Suborder Adeleorina, Family Haemogregarinidae was recorded in turtles [2], lizards [3,4] and crocodiles [5]. Haemogregarina species infect lower vertebrates as intermediate hosts and leeches as definitive hosts. The pattern of sporogony followed by merogony and migration of merozoites to the salivary tissue prior to infecting the next host appears to be common to all haemogregarines that utilize leeches as their definitive hosts [6]. An infected leech feeding on reptiles injects merozoites into the bloodstream initiating the preerythrocytic merogony in the lungs, liver and spleen of the reptile host, producing about 18 merozoites. Secondary merogony takes place in the erythrocytes where different parasitic stages including the gamonts are formed [2,7-9].

The most important tools to learn about the physiological adaptations of reptiles to special environmental conditions are haematology and blood cytology [10]. Blood smears stained with Diff Quick are the initial tool for cytological diagnosis of Haemogregarina spp. However, the development of sensitive and specific molecular methods (e.g. PCR) enabled the detection and identification of parasites in the sample, as well as the investigation and elucidation of the evolutionary relationships of adeleorinid parasites within the Apicomplexa [11,12].

No previous work has been conducted on the prevalence and intensity of parasitemia, as well as on cytological and molecular identification of haemogregarines in protected species of European pond turtle (Emys orbiculars) in Serbia. The current study is aimed to the cytological investigation and molecular identification of the hemoparasites in E. orbicularis from the quarantine section at Belgrade Zoo, based on intraerythrocytic parasitic forms and $18 \mathrm{~S}$ rDNA sequence, respectively, showing poor health condition and massive skin hemorrhages.

\section{MATERIAL AND METHODS}

\section{Animals}

Thirty (15 male and 15 female) European pond turtles (E. orbicularis) aged from 5 to 15 years, seized in transit through Serbia and temporarily held in the quarantine section at Belgrade Zoo, have been found in poor health condition, with general weakness and anorexia. Clinical signs consisted also of necrotic ulcerations of the shell and skin, as well as massive skin hemorrhages. In addition six adult clinically healthy European pond turtles ( 3 male and 3 female) served as control animals in this investigation. 
Each tested turtle was marked with a unique identification number stamped on the marginal scute. After clinical investigation, which included inspection and palpation, as well as detailed macroscopic examination of the skin, plastron and carapace, blood samples were taken for cytological, hematological and biochemical analysis as well as for molecular identification (PCR).

\section{Blood smears}

Blood samples $(2-3 \mathrm{ml}$ ) from all 36 European pond turtles (E. orbicularis) were collected from the subvertebral vein sinus using $23 \mathrm{G} \times 1$ Luer needles. Blood smears were prepared immediately on microscopic slides and air-dried at $18-20^{\circ} \mathrm{C}$ for 1 hour. Air dried and fixed hematological smears were stained with Diff Quick (Hemacolor ${ }^{\mathbb{R}}$ Merck). The stained slides were examined with the immersion objective on Olympus BX $51^{\circledR}$ microscope (Olympus, Japan). Pictures were taken with Olympus Color View III ${ }^{\circledR}$ digital camera (Olympus, Japan).

\section{Biochemical and hematological analysis}

Whole blood was placed in heparinized tubes, centrifuged immediately, than plasma was frozen $\left(-20^{\circ} \mathrm{C}\right)$ and analysed within 24 hours using an automated analyser (Biosystems A15, Biosystems, Spain) for total protein (TP), glucose, alanine aminotransferase $($ ALT), aspartate aminotransferase (AST), phosphorus $(\mathrm{P})$, calcium $(\mathrm{Ca})$ and iron $(\mathrm{Fe})$. Haematocrit was measured by microhaematocrit tubes. Haemoglobin $(\mathrm{Hb})$ and total red and white cell counts were determined by analyser ADVIA 120 (Siemens, Germany).

\section{Molecular investigation}

\section{DNA extraction}

From each turtle, $200 \mu \mathrm{l}$ of blood was used for DNA extraction. The extraction was performed using the commercial set "GeneJET Whole Blood Genomic DNA Purification Mini Kit” (Thermo Scientific, USA; Cat. No K0781) according to manufacturer's instructions.

\section{PCR}

For PCR amplification we used primers (EF: 5'-GAAACTGCGAATGGCTCAT'T-3' and ER: 5'-CTTGCGCCTACTAGGCAT'TC-3') designed by Kvičerová et al. (2008) [13] and amplifying up to $1500 \mathrm{bp}$ long fragments of $18 \mathrm{~S}$ rRNA gene sequence of Haemogregarina. Amplifications were performed in $25 \mu$ l reactions containing: $1 \mathrm{x}$

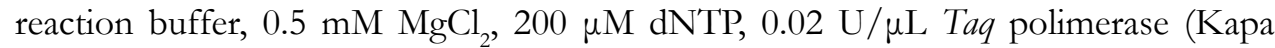
Biosystems, USA) and $0.4 \mu \mathrm{M}$ of each primer. The reaction was performed with $3 \mu \mathrm{L}$ 
of DNA tamplate. For all amplifications, MultiGene Gradient PCR thermocycler (Labnet International Inc, USA) was used. The thermal protocol consisted of an initial denaturation step at $95^{\circ} \mathrm{C}$ at $4 \mathrm{~min}$, followed by 35 cycles of denaturation $\left(95^{\circ} \mathrm{C}\right.$, $30 \mathrm{sec})$, annealing $\left(58^{\circ} \mathrm{C}, 30 \mathrm{sec}\right)$ and DNA extension $\left(72^{\circ} \mathrm{C}, 90 \mathrm{sec}\right)$ with the final extension step at $72^{\circ} \mathrm{C}$ for $10 \mathrm{~min}$. DNA obtained from Haemogregarina stepanowi was used as a positive control for PCR, while DNA/RNA free water was used as negative control. After PCR amplification, the PCR products were visualized with UV light after staining the $2 \%$ agarose gel with ethidium bromide. A commercial O'RangeRulerTM 100bp DNA Ladder (Fermentas, Lithuania) was used as a molecular size marker.

\section{DNA sequencing}

Obtained PCR products were directly sequenced in two directions using the BigDye ${ }^{\circledR}$ Terminator method in an ABI 3730XL automatic DNA sequencer (Macrogen Europe, The Netherlands). Sequence similarity analysis was performed using the BioEdit version 7.2 .5 [14] and Clustal W software.

\section{Ethics}

All European pond turtles (E. orbicularis) as protected animal species were examined according to the national law on the care and considering all ethical requirements. The investigation was done with permission of the Ministry of Agriculture and Environmental Protection of the Republic of Serbia and the blood samples were obtained for analyses under permission code 119-01-13-2-2015-09.

\section{RESULTS}

\section{Clinical investigation}

Infection of European pond turtles (E. orbicularis) with Haemogregarina sp. was present in 30/30 (100\%) examined animals. All 30 turtles included in this study were found with severe shell necrosis on the plastron and carapace, as well as massive skin hemorrhages mostly in the inguinal regions (Figures 1). No Haemogregarina sp. were present in the blood of 6 clinical healthy control turtles. In addition, no leeches were detected on Haemogregarina-positive or clinically healthy turtles. 

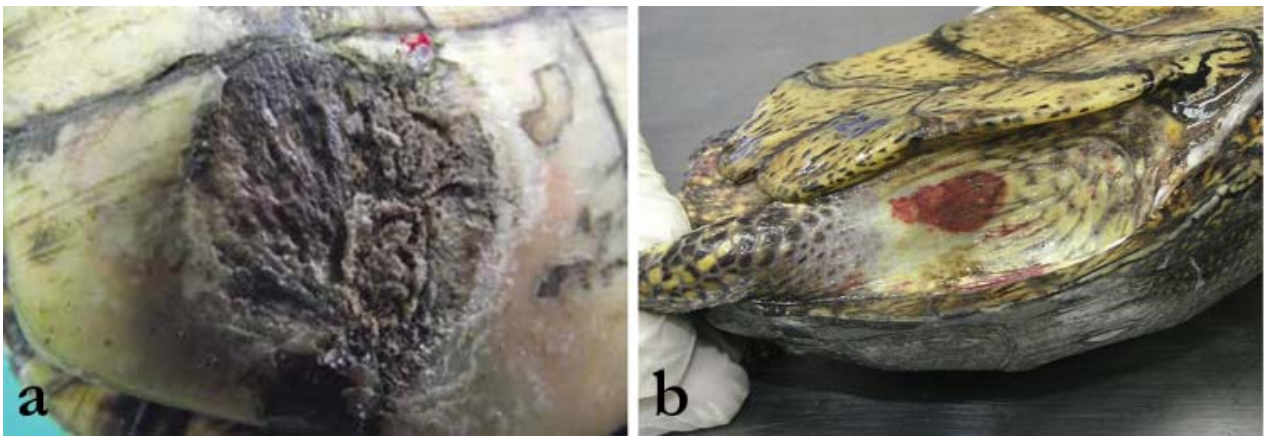

Figure 1. Macroscopic changes, a) Shell necrosis on the plastron; b) Massive skin hemorrhages in the inguinal region

\section{Blood smears cytology}

On the blood smears of all 30 animals, infected erythrocytes showed signs of alteration in shape and size. Altered red blood cells often were elongated, curved, pear-shaped with eccentric and atrophic nuclei. Parasite species and their characteristics were identified according to Telford [15].

Premeront (Figure 2a) and U-shaped gamont (Figure 2b) of the Haemogregarina sp. were noticed inside the erythrocytes in the peripheral blood.

No infected erythrocytes were found in 6 clinically healthy turtles from the control group.
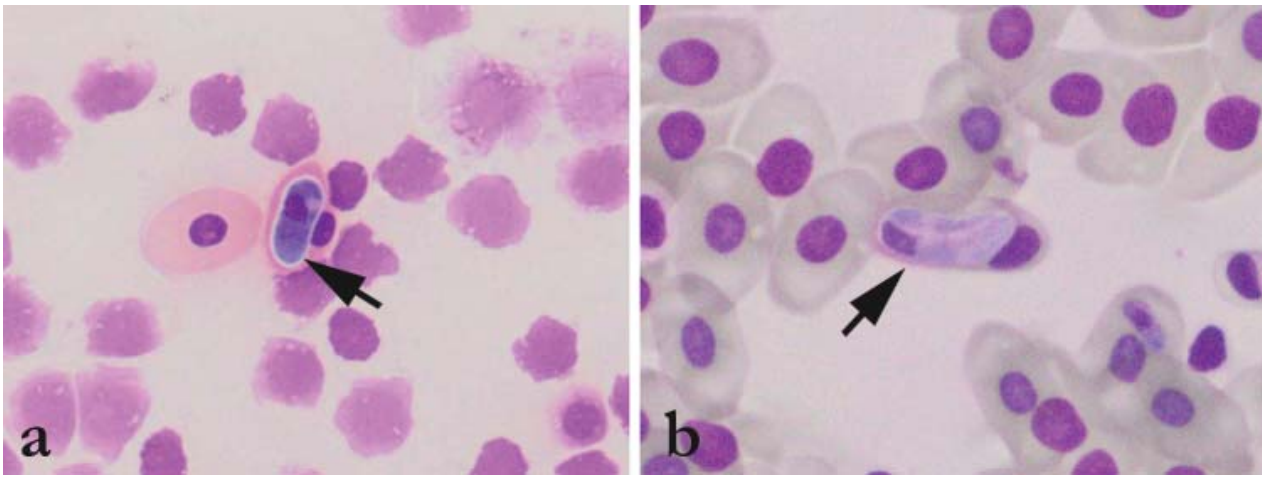

Figure 2. European pond turtle blood smear, a) Premeront of the Haemogregarina stepanowi (arrow); b) U-shaped gamont of Haemogregarina stepanowi (arrow) with eccentric nucleus of the erythrocyte, Diff Quick

\section{Biochemical and hematological analysis}

Biochemical analysis indicated lower values of AST, ALT and iron concentration in most of the infected turtles while hematological analysis showed changes of hematocrit, decrease in the number of red blood cells and low hemoglobin levels in 
the blood (Table 1). The other parameters and values obtained by analyzing samples originating from 6 clinically healthy turtles were within the normal range.

Table 1. Some biochemical and hematological values of turtles infected with Haemogregarina stepanowi

\begin{tabular}{|c|c|c|c|c|c|c|}
\hline & $\begin{array}{l}\text { Erythrocyte } \\
\times 10^{9} \text { cell } / \mathrm{ml} \\
\end{array}$ & $\begin{array}{c}\text { Hemoglobin } \\
(\%)\end{array}$ & $\begin{array}{c}\text { Hematocrit } \\
(\%)\end{array}$ & $\begin{array}{l}\text { ALT } \\
\text { IU/L }\end{array}$ & $\begin{array}{c}\text { AST } \\
\text { IU/L }\end{array}$ & $\begin{array}{c}\mathrm{Fe} \\
\mu \mathrm{mol} / \mathrm{L}\end{array}$ \\
\hline $\begin{array}{l}\text { Ref. } \\
\text { values }\end{array}$ & $0.5-1.5$ & $5-8.4$ & $18-25$ & $2.9-20.3$ & $81.2-197.2$ & $8.96-18.27$ \\
\hline 1 & 0.3 & 3.4 & 12.0 & 5.6 & 71.0 & 6.9 \\
\hline 2 & 0.5 & 5.8 & 22.0 & 12.1 & 494.4 & 0.9 \\
\hline 3 & 0.6 & 6.2 & 24.0 & 3.8 & 37.8 & 8.5 \\
\hline 4 & 0.4 & 4.0 & 15.0 & 3.5 & 46.3 & 5.2 \\
\hline 5 & 0.7 & 7.7 & 28.0 & 4.2 & 92.4 & 8.3 \\
\hline 6 & 0.6 & 6.0 & 23.0 & 4.7 & 103.0 & 8.9 \\
\hline 7 & 0.5 & 4.9 & 9.0 & 2.0 & 96.4 & 5.9 \\
\hline 8 & 0.3 & 3.0 & 10.5 & 3.5 & 49.2 & 1.9 \\
\hline 9 & 0.3 & 3.1 & 12.0 & 6.5 & 118.3 & 15.3 \\
\hline 10 & 0.4 & 3.7 & 13.0 & 5.1 & 82.2 & 0.3 \\
\hline 11 & 0.4 & 3.9 & 15.0 & 0.1 & 19.5 & 9.8 \\
\hline 12 & 0.6 & 6.0 & 23.0 & 0.9 & 37.9 & 11.4 \\
\hline 13 & 0.4 & 4.2 & 15.0 & 4.8 & 96.1 & 7.9 \\
\hline 14 & 0.6 & 6.5 & 24.0 & 3.7 & 90.8 & 12.8 \\
\hline 15 & 0.4 & 3.4 & 12.0 & 4.2 & 93.1 & 15.0 \\
\hline 16 & 0.4 & 4.0 & 15.0 & 3.9 & 65.7 & 2.3 \\
\hline 17 & 0.4 & 4.2 & 16.0 & 3.3 & 69.0 & 11.9 \\
\hline 18 & 0.3 & 3.3 & 13.0 & 4.0 & 90.3 & 12.5 \\
\hline 19 & 0.3 & 3.1 & 12.0 & 2.3 & 28.7 & 0.1 \\
\hline 20 & 0.3 & 2.7 & 11.0 & 7.9 & 96.4 & 74.1 \\
\hline 21 & 0.5 & 5.3 & 19.0 & 2.4 & 73.5 & 12.8 \\
\hline 22 & 0.5 & 5.3 & 19.0 & 9.1 & 65.9 & 8.9 \\
\hline 23 & 0.3 & 3.0 & 10.5 & 2.9 & 23.2 & 2.2 \\
\hline 24 & 0.4 & 3.5 & 12.0 & 2.9 & 76.2 & 7.9 \\
\hline 25 & 0.1 & 1.0 & 5.0 & 5.0 & 59.0 & 3.3 \\
\hline 26 & 0.1 & 1.5 & 7.0 & 3.0 & 36.1 & 12.3 \\
\hline 27 & 0.1 & 1.7 & 8.0 & 4.3 & 48.3 & 0.3 \\
\hline 28 & 0.3 & 3.2 & 15.0 & 4.4 & 70.9 & 5.2 \\
\hline 29 & 0.3 & 3.3 & 15.0 & 5.1 & 80.2 & 0.3 \\
\hline 30 & 0.5 & 3.5 & 16.0 & 3.5 & 90.2 & 5.2 \\
\hline
\end{tabular}




\section{Molecular investigation (PCR)}

The amplifications of $18 \mathrm{~S}$ rDNA sequence were detected microscopically in 30/30 $(100 \%)$ Haemogregarina-positive turtles. All PCR products were of the same size as the amplicon of $H$. stepanowi that was used as a positive control (Figure 3).

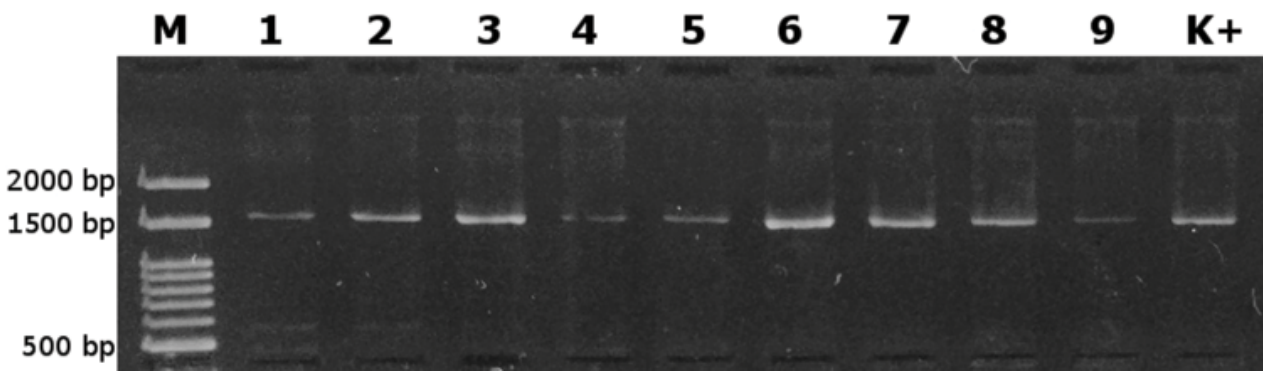

Figure 3. PCR amplicons of Haemogregarina 18S rDNA sequence; M - Ladder, 1-9 - Tested samples, $\mathrm{K}+$ Positive control

In addition, $18 \mathrm{~S}$ rDNA sequences from our study were identical for all samples [GenBank Accession Number KT749877; http://www.ncbi.nlm.nih.gov], showing $100 \%$ nucleotide similarity with $18 \mathrm{~S}$ rRNA gene sequence of H. stepanowi [GenBank Acc. No KF257927; http://www.ncbi.nlm.nih.gov]. No amplifications were observed in 6 clinically healthy turtles from the control group.

\section{DISCUSSION}

Water pollution is known to play an important role in the pathogenesis of a number of plastron, carapace and skin diseases in European pond turtles (E. orbicularis). Due to the wet habitat, a number of bacteria can invade the organism via mechanical lesions of the shell [16] and mycoses were often described to be the cause of shell necroses $[17,18]$. The alterations in haematocrit, number of erythrocytes and haemoglobin concentration, basophilia, eosinophilia, heterophilia, and azurophilia can be regarded as typical of turtles suffering from chronic infections, undernourishment and chronic stress [19]. Furthermore, different environmental characteristics could affect the occurrence, prevalence and intensity of haemoparasites in turtles.

No previous work has been conducted on the prevalence and intensity of parasitemia of haemogregarines in protected species of European pond turtles in Serbia. In our study thirty European pond turtles E. orbicularis aged from 5 to 15 years, from the quarantine section at Belgrade Zoo, have been found in poor health condition, with anemia, general weakness and anorexia. No significant difference on the prevalence of Haemogregarina sp. was detected between males and females. However, in some studies females were found to be more prone to haemogregarine infection than males [20]. All thirty infected turtles from the quarantine section at Belgrade Zoo were found with severe shell necrosis on the plastron and carapace as well as massive skin hemorrhages 
mostly in the inguinal region. The infected turtles were adults aged from 5 to 15 years. The larger size of adults promote them as a better target to leech attachment because of their larger surface area and also turtles with a longer life span were more exposed to leeches [21]. Therefore, the lower prevalence of haemogregarine infection in basking species could be attributed to a reduction in leech exposure, and an increase in the host immune response.

Some of the most important tools to learn about the physiological adaptations of reptiles to special environmental conditions are hematology and blood cytology. The biological cycle of the parasite causes the destruction of the infected erythrocytes, potentially leading to blood regeneration [10]. However, our results on the blood smears of all 30 infected European pond turtles show altered red blood cells. Erythrocytes were elongated, curved, pear-shaped with eccentric and atrophic nuclei. Different life cycle stages of the Haemogregarina sp. were noticed inside the erythrocytes in the peripheral blood. These protozoa had an intracellular location, therefore the affected erythrocytes had a marginalized nucleus and increased cell size. The parasites according to disposition, aspect, shape and morphology, cytological identification of the species were concordant with Genus Haemogregarina, Family Haemogregarinidae [15].

It has been stated that chelonians are extremely hardy animals and can be normally active even when they have a severe anemia [22]. The analysis of the hematological values shows that animals infected with $H$. stepanowi have lower values of hematocrit, hemoglobin and red blood cell count comparing to the reference values which are expected based on the results of Thrall et al. (2004) [23] and Stacy et al. (2011) [24] who stated that blood parasites are commonly found in reptiles and are usually associated with anemia.

Our results show lower values of AST, ALT and iron concentrations than values obtained by authors who sampled healthy turtles [25]. Unfortunately, there are no other results related to turtles infected by hemoparasites so any comparison was not possible. However, since hemoparasites affect the general condition of the animals [24] it can be assumed that they have an impact on blood enzymes values.

However, definitive identification via molecular testing was performed in order to obtain the molecular and genetical identification of Haemogregarina sp. in European pond turtles investigated in the current study. Using PCR, we detected amplifications in 30/30 (100\%) turtles with clinical symptoms. In addition, all obtained sequences were $100 \%$ identical to the previously published $18 \mathrm{~S}$ rDNA sequence of $H$. stepanowi (GenBank Acc. No KF257927). Detection of this haemoparasite species in European E. orbicularis from the current study is in line with results of Mihalca et al. (2002, 2008) $[26,27]$ who also reported $100 \%$ prevalence in the same host species from Romania. In addition, Dvoŕáková et al. (2014) [12] found that haemogregarines detected in four western Palearctic hard-shelled freshwater turtle species were conspecific with H. stepanowi, with the highest prevalence observed in E. orbicularis (86.7\%). The high prevalence of infected turtles in our study could be the result of analyzing individuals 
from an isolated turtle population with visible clinical signs. However, the high prevalence of Haemogregarina infection does not need to be correlated to the health condition of the reptile hosts, since Mihalca et al. (2008) [27] reported 100\% prevalence in turtles without any clinical signs. Consistency between the results obtained by blood smear microscopy and PCR in the current study suggests the same sensitivity of both applied diagnostic methods, as it was previously reported in the study of Dvořáková et al. (2014) [12].

Bielecki et al. (2012) [28] observed the close association of Placobdella costata (the leech species vectoring $H$. stepanowi) and E. orbicularis, with intensity of leech invasion being related to the host size and body weight. Although no leeches were found infesting turtles in our study, high prevalence of $H$. stepanowi infection in intermediate hosts indicates the presence of the leech vector at the same collection site. Moreover, Haemogregarina sp. was considered to be low host-specific crossing the family level of its intermediate hosts [12]. However, future research concerning H. stepanowi in Serbia should give the answer if the same conclusion can also be applied to its definitive host i.e. the leech.

\section{Acknowledgements}

The investigation was supported by the Ministry of Education, Science and Technological Development of the Republic of Serbia, Project III 46002

We would like to thank Prof. Pavel Široký for providing H. stepanowi DNA used as a positive control in PCR.

\section{REFERENCES}

1. Knotkova Z, Mazanek S, Hovorka M, Sloboda M, Knotek Z: Haematology and plasma chemistry of Bornean river turtles suffering from shell necrosis and haemogregarine parasites. Vet Med - Czech 2005, 50:421-426.

2. Siddall ME, Desser SS: Prevalence and intensity of Haemogregarina balli (Apicomplexa: Adeleina: Haemogregarinidae) in three turtle species from Ontario, with observations on intraerythrocytic development. Can J Zool 1992, 70:123-128

3. Amo L, Fargallo JA, Martınez-Padilla J, Millan J, Lopez P, Martın, J: Prevalence and intensity of blood and intestinal parasites in a field population of a Mediterranean lizard, Lacerta lepida. Parasitol Res 2005, 96:413-417.

4. Peirce MA, Adlard RD: Haemoparasites from clinical screening of reptiles in South-East Queensland, Australia. Vet Rec 2004, 155:708-709.

5. Khan RA, Forrester DJ, Goodwin TM, Ross CA: A haemogregarine from the American alligator (Alligator mississippiensis). J Parasitol 1980, 66:324-332.

6. Siddall ME, Desser SS: Ultrastructure of merogonic development of Haemogregarina (sensu lato) myoxocephali (Apicomplexa: Adeleina) in the marine leech Malmiana scorpii and localization of infective stages in the salivary cells. Eur J Protistol 1993, 29:191-201. 
7. Siddall ME, Desser SS: Gametogenesis and sporogonic development of Haemogregarina balli (Apicomplexa: Adeleina: Haemogregarinidae) in the leech Placobdella ornata. J Protozool 1990, 37:511-520.

8. Siddall ME, Desser SS: Merogonic development of Haemogregarina balli (Apicomplexa: Adeleina: Haemogregarinidae) in the leech Placobdella ornata (Glossiphoniidae), its transmission to a chelonian intermediate host and phylogenetic implications, J Parasitol 1991, 77: 426-436.

9. Olsen OW: Animal Parasites: Their Life Cycles and Ecology, 3rd edition, Dover Publications; 1986.

10. Martínez-Silvestre A, Lavín S, Cuenca R: Hematología y citología sanguínea en reptiles. Clínica Veterinaria de Pequeños Animales 2011, 31:131-141.

11. Barta JR, Ogedengbe JD, Martin DS, Smith TG: Phylogenetic position of the adeleorinid coccidia (Myzozoa, Apicomplexa, Coccidia, Eucoccidiorida, Adeleorina) inferred using $18 \mathrm{~S}$ rDNA sequences. J Eukaryot Microbiol 2012, 59:171-180.

12. Dvorakova N, Kvicerova J, Papousek I, Javanbakht H, Tiar G, Kami HG: Haemogregarines from western Palaearctic freshwater turtles (genera Emys, mauremys) are conspecific with Haemogregarina stepanowi Danilewsky, 1885. Parasitology 2014, 141:522-530.

13. Kvičerova J, Hypša V, Pakandl M: Phylogenetic relationships among Eimeria spp. (Apicomplexa,Eimeriidae) infecting rabbits: evolutionary significance of biological and morphological features. Parasitology 2008, 135: 443-452.

14. Hall TA: BioEdit: a user-friendly biological sequence alignment editor and analysis program for Windows 95/98/NT. Nucl Acid S 1999, 41:95-98.

15. Telford SR: Hemoparasites of the reptilia: Color atlas and text. Boca Raton, Florida: CRC Press, Taylor and Francis Group; 2009.

16. Aleksić-Kovačević S, Özvegy J, Krstić N, Rusvai M, Jakab C, Stanimirovic Z, Becskei Z: Skin and skeletal system lesions of european pond turtles (Emys orbicularis) from natural habitats. Acta Vet Hung 2014, 62:180-193.

17. Joyner PH, Shreve AA, Spahr J, Fountain AL, Sleeman JM: Phaeohyphomycosis in a freeliving eastern box turtle (Terrapene carolina carolina). J Wildl Dis 2006, 42:883-888.

18. Orós J, Calabuig P, Arencibia A, Camacho M, Jensen HE: Systemic mycosis caused by Trichophyton spp. in an olive ridley sea turtle (Lepidochelys olivacea): An immunohistochemical study. New Zeal Vet J 2011, 59:92-95.

19. Knotkova Z, Knotek Z, Hajkova P: Plasma biochemistry of chelonians of the Geochelone group. In: Proceedings of Annual Meeting of European Association of Zoo- and Wildlife Veterinarians, 31. 5.-4. 6. 2000, Paris, 281-285.

20. Molla SH, Bandyopadhyay PK, Gürelli G: On the Occurrence of a Haemogregarinae (Apicomplexa) Parasite from freshwater Turtles of South 24 Parganas, West Bengal, India. Turkiye Parazitolojii Dergisi 2013, 37:118- 122.

21. McCoy JC, Failey EL, Price SJ, Dorcas ME: An assessment of leech parasitism on semi aquatic turtles in the Western Piedmont of North Carolina. Southeast Nat 2007, 6:191-202.

22. Norton TM: Chelonian emergency and critical care. Seminars in avian and exotic pet medicine 2005, 14:106-130.

23. Thrall MA, Dale C, Baker E, Lassen ED: Hematology of reptiles. In: Veterinary hematology and clinical chemistry. Pennsylvania, USA: Lippincott Williams \& Wilkins; 2004, 259-276.

24. Stacy NI, Alleman AR, Sayler KA: Diagnostic hematology of reptiles. Clin Lab Med 2011, 31:87-108. 
25. Metin K, Turkozan O, Kargin F, Koca BY, Taskavak E, Koca S: Blood cell morphology and plasma biochemistry of the captive European pond turtle Emys orbicularis. Acta Veterinaria Brno 2006, 75:49-55.

26. Mihalca AD, Achelăriței D, Popescu P: Haemoparasites of the genus Haemogregarina in a population of european pond turtles (Emys orbicularis) from Drăgăşani, Vâlcea county, Romania. Rev Sci Parasitol 2002, 3:22-27.

27. Mihalca AD, Racka K, Gherman C, Ionescu DT, Prevalence and intensity of blood apicomplexan infections in reptiles from Romania. Parasitol Res 2008, 102:1081-1083.

28. Bielecki A, Cichocka JM, Jabłoński A, Jeleń I, Ropelewska E, Biedunkiewicz A, Terlecki J, Nowakowski JJ, Pakulnicka J, Szlachciak J. Coexistence of Placobdella costata (Fr. Müller, 1846) (Hirudinida: Glossiphoniidae) and mud turtle Emys orbicularis. Biologia 2012, 67:731738.

\title{
CITOLOŠKA I MOLEKULARNA IDENTIFIKACIJA
} HEMOPARAZITA HAEMOGREGARINA STEPANOWI U KRVNIM RAZMAZIMA BARSKIH KORNJAČA (EMYS ORBICULARIS) POREKLOM IZ KARANTINA U ZOO VRTU BEOGRAD

\author{
ÖZVEGY Jòzsef, MARINKOVIĆ Darko, VUČIĆEVIĆ Miloš, GAJIĆ Bojan, \\ STEVANOVIĆ Jevrosima, KRNJAIĆ Dejan, ALEKSIĆ-KOVAČEVIĆ Sanja
}

Krvni razmazi bojeni Diff Quick metodom predstavljaju inicijalni korak u postavljanju dijagnoze kod infekcije izazvane hemoparazitom Haemogregarina sp. Razvoj senzitivnih i specifičnih molekularnih tehnika omogućava detekciju i identifikaciju parazita u uzorcima i bližu evolutivnu povezanost sa podredom Adeleorina i poziciju unutarrazdela Apicomplexa. Cilj ovih istraživanja bio je citološka i molekularna identifikacija hemoparazita kod trideset barskih kornjača (Emys orbicularis) privremeno smeštenih u karantinu Zoo-vrta Beograd, a koje su imale kliničke simptome opšte slabosti, masivna krvavljenja u koži i nalaz različitih razvojnih stadijuma intraeritrocitnih parazita u krvnom razmazu. Biohemijske analize ukazale su na niže vrednosti AST i gvožđa, kod većine inficiranih kornjača dok je hematološkim analizama uočena promena vrednosti hematokrita i pad broja eritrocita i nivoa hemoglobina u krvi. Amplifikacijom 18 s rDNK sekvence hemogregarine, parazit je detektovan kod 30/30 (100\%) kornjača sa navedenim kliničkim simptomima. Svi PCR produkti bili su iste veličine kao i amplifikat $H$. stepanowi koji je upotrebljen kao pozitivna kontrola. Buduća ispitivanja $H$. stepanowi u Srbiji treba da se izvedu na definitivnom domaćinu - pijavicama. 